Irq J Pharm Vol. ${ }^{9} \& 1 \cdot$, No. ${ }^{\prime}$,

$r, 1$.

\title{
Seroepidemiological study of mumps in Mosul
}

\author{
Tariq M. Quasim \\ Department of Pharmacology, College of Pharmacy \\ University of Mosul, Iraq.
}

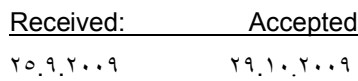

\begin{abstract}
Objectives: to evaluate the prevalence of mumps specific IgG antibodies in sera of different age groups and sexes of Mosul population.

Methods: $\leqslant \varepsilon \cdot$ sera of different age groups and sexes were collected and tested by ELISA test.

Results: Seropositivity against mumps virus among different age groups was $\uparrow \wedge \%$ (males $\uparrow \uparrow \%$ and females $r$ r\%, the difference was not significant). However, significant differences $(p<\cdot .0)$ were seen among males and females at different age groups.

Conclusion: Seropositivity in age group $\cdot-9$ years which was within the introduction of MMR was the lowest. indicating that the level of immunity developed by MMR vaccine was below the herd immunity threshold.
\end{abstract}

Key words: Mumps, serological test, IgG antibodies

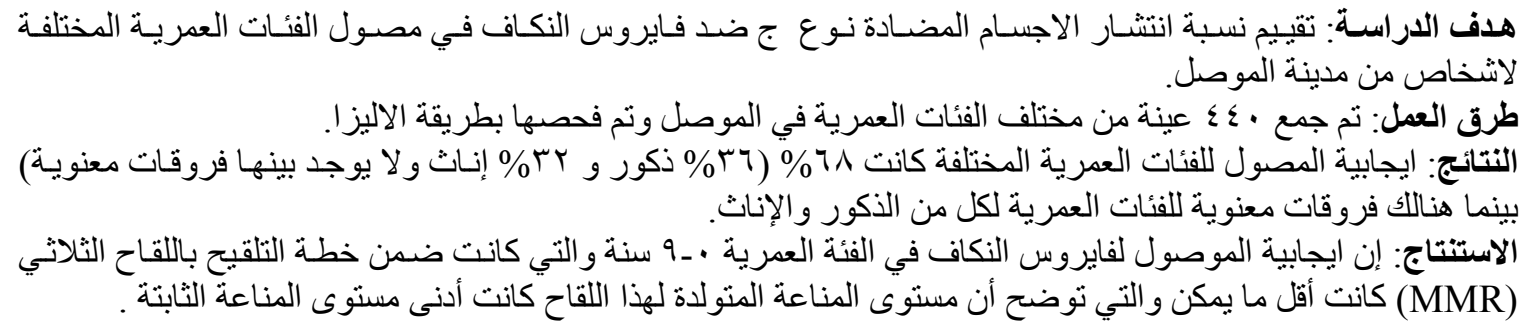

M umps is an acute infectious disease of children and young adults, caused by paramyxovirus, an enveloped single stranded RNA virus.' Mumps infection is seen in all year around and cases are accumulating during winter. In countries of tropical and subtropical zone, mumps is an infection of early childhood. The virus is transmitted by droplet or direct contact and the primary site of replication is the epithelial cells of upper respiratory tract. ${ }^{\top}$

Infection begins with moderate to sever prodromal stage followed by enlargement of one or more of the salivary gland (primarily parotid glands). Since the introduction of the vaccine, there has been progressive decline in the number of reported cases of mumps all over the world and the immunity induced by vaccine should last through childhood depending on the type of vaccines." The prevalence of mumps infection in population is indicated by seropositivity rates which vary in different countries. However, during the past few years there were cumulative reports on the occurrence of relatively large mumps epidemics in countries with routine immunization against the disease."

The current study is designed to test the sera of population of Mosul city at different ages for mumps antibodies using ELISA test.

\section{Materials and Methods}

\section{Sera}

Venous blood (0-1. ml) was collected in plane tubes from $\leqslant \varepsilon$. of people of both sexes attended hospitals in Mosul city during $r . . v$. Sera were separated by centrifugation at $r . .$. rpm for $r$. minutes and stored at $-r$. ${ }^{\circ} \mathrm{C}$ until the time of the assay. The target number of sera to be tested for each group followed the European Seroepidemiology Network guidelines. ${ }^{\wedge}$ 
Irq $\mathrm{J}$ Pharm Vol. ${ }^{9} \& 1 \cdot$, No. ${ }^{\prime}$, r. I.

\section{Serological Test}

Mumps specific IgG antibodies were determined using ELISA test (Abbott mumps antibodies) for quantitative measurement of specific lgG antibodies against mumps virus in human sera. ELISA test was performed according to the manufacturer instructions.

Data were analysed statistically using Wilcoxon Sank Test and Mann-Whitney Confidence Interval and Test.

\section{RESULTS}

The distribution of sera according to sex was rrr males (or.v\%) and $r \cdot \wedge$ females ( $\leqslant \vee . r \%$ ) The distribution of different age groups of both sexes and seropositivity to mumps virus is shown in Table 1 and Table $r$. The percentage of seropositivity among different age groups in male was $r r \%$ and females $r r \%$ which is not significant. However, significant differences were seen among male at the different age groups $(P<\cdot \cdot 0)$, and female at different age groups $(P<\because \cdot 0)$. The total percentage of seropositivity in all sera tested was $\uparrow \wedge \%$ and significant difference $(P<\cdot .0)$ was seen among different age groups (Table ${ }^{\top}$ ).

The incidence of mumps seropositivity in the sera of different age group as measured by ELISA is shown in Figure 1. Mumps antibodies were detected in $00 \%$ of the sera in the.-9 age group, while in the $1 .-19$ age group the incidence was $09 \%$ and that of age group $r \cdot-r q$ was $r . \%$. However, in sera from individuals $\geq r$. years of age, high incidence of mumps antibodies ( $\vee \circ \%-\Lambda \cdot \%)$ except age group $7 .-79$ years old.

Table 1: The distribution of male sera at different age groups and seropositivity to mumps virus

\begin{tabular}{|c|c|c|}
\hline Age groups & No. of samples tested & $\%$ of positive \\
\hline$\cdot-9$ years & 7. & rᄉ \\
\hline $1 .-19$ years & 01 & ro \\
\hline$r \cdot-r q$ years & TV & $r \varepsilon$ \\
\hline$r \cdot-r q$ years & 11 & rq \\
\hline$\varepsilon \cdot-\leqslant q$ years & $r$. & rᄉ \\
\hline 0.09 years & YT & $\S$ \\
\hline $7 .-79$ years & $r$. & $\leqslant V$ \\
\hline
\end{tabular}

Table $r$ : The distribution of female sera at different age groups and seropositivity to mumps virus

\begin{tabular}{|c|c|c|}
\hline Age groups & No. of samples tested & \% of positive \\
\hline$\cdot-9$ years & or & $r v$ \\
\hline $1 \cdot-19$ years & $r q$ & $r \tau$ \\
\hline$r \cdot-r q$ years & $r$ & $\varepsilon \tau$ \\
\hline$r \cdot-r q$ years & $r q$ & \\
\hline$\varepsilon \cdot-\varepsilon q$ years & $r r$ & \\
\hline
\end{tabular}


Irq $\mathrm{J}$ Pharm Vol. ${ }^{9} \& 1 \cdot$, No. ${ }^{\prime}$,

$r+1$.

\begin{tabular}{|c|c|c|}
\hline 0.09 years & ro & $r 9$ \\
\hline $7 .-79$ years & 1 & 19 \\
\hline
\end{tabular}

Table r: The distribution of total sera at different age groups and seropositivity to mumps virus.

\begin{tabular}{|c|c|c|}
\hline Age groups & No. of samples tested & $\%$ of positive \\
\hline$\cdot-9$ years & $11 \mathrm{~V}$ & 00 \\
\hline $1 .-19$ years & $\Lambda \mathrm{V}$ & 09 \\
\hline$r \cdot-r_{q}$ years & $\varepsilon V$ & 7. \\
\hline$r \cdot-r q$ years & $\varepsilon V$ & vo \\
\hline$\varepsilon \cdot-\varepsilon q$ years & Tr & $\wedge$. \\
\hline $0 . .09$ years & 01 & $\wedge$. \\
\hline $7 .-79$ years & rA & 77 \\
\hline
\end{tabular}

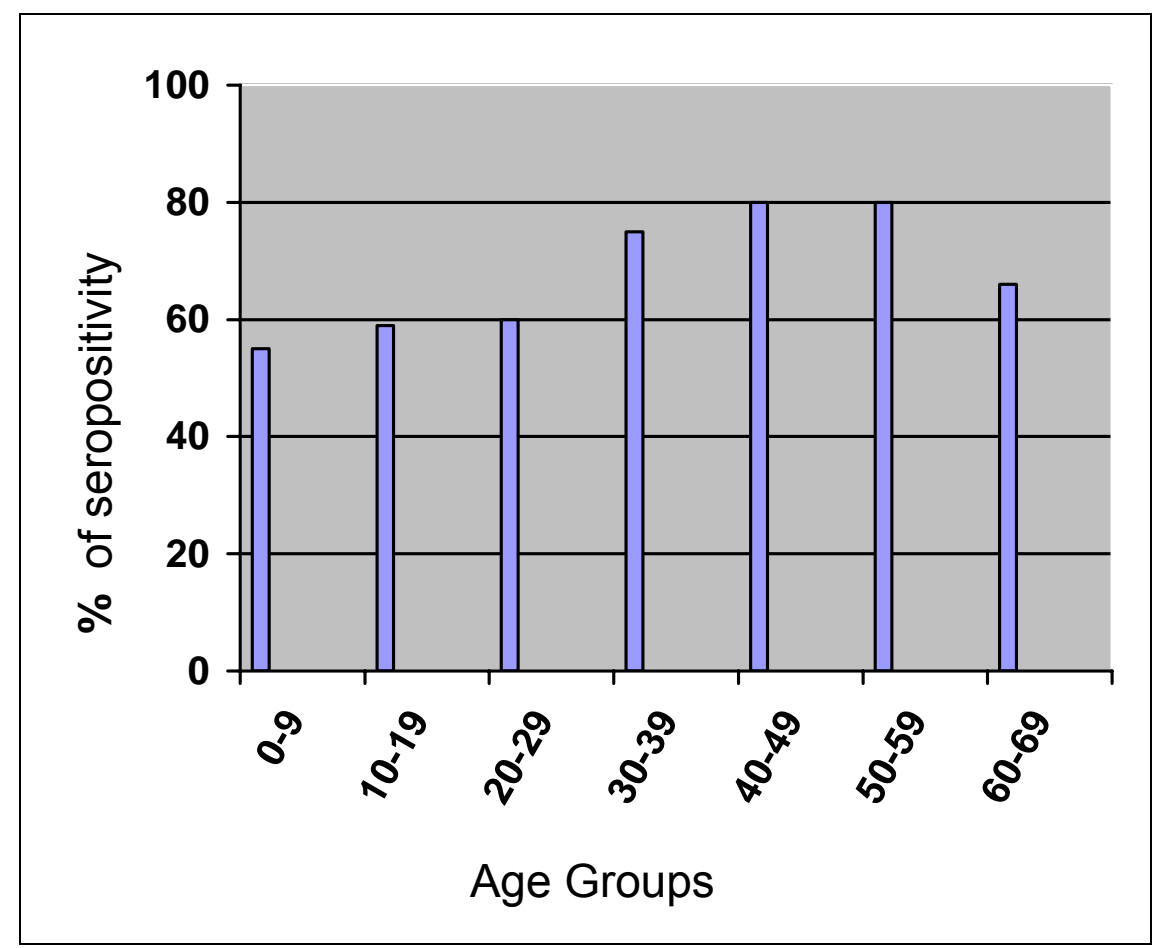

Figure 1. The incidence of mumps seropositive in age group sera from Mosul population as measured by ELISA. 
Irq J Pharm

Vol. ${ }^{9} \& 1 \cdot$, No. ' ,

$r, 1$.

\section{Discussion}

Important advances in the knowledge and understanding of infectious diseases have been made by seroepidemiological studies. Such studies will continue to be of value as changing epidemiological and social factors influencing the incidence and severity of variety of infections. Serosurveys have a valuable role in the assessment of the level of immunity to mumps following natural infection or vaccination and may lead to identification of subpopulation at an increased risk for mumps outbreak.

The current study was carried out to assess mumps antibodies in sera of people of Mosul city attending different hospitals measured by ELISA which is shown as sensitive and specific.

There have been many reported surveys for mumps antibodies in different parts all over the world, ${ }^{\{, T, Y, i r}$ but non in Mosul city. MMR vaccine was first introduced in Iraq in 1997; therefore, the first age group ( $\cdot-9$ years old) was involved in the vaccination programe. The rest of groups were not vaccinated. We really do not know whether those who were vaccinated had single or two doses.

The seropositivity of vaccinated group 1 who received at least single dose was $00 \%$. which is much lower than in other countries. ${ }^{1 Y-}$ This can be explained probably by low vaccination coverage to this age group or having single dose of the vaccine or failure of the vaccine to elucidate high antibody titer. Reports from Ministry of Health showed outbreaks of mumps vaccinated in young age group. Recent outbreaks have been described among two doses recipients ${ }^{T, \gamma, 10}$.

The high incidence of seropositivity to mumps virus in other age groups (not vaccinated) probably explained by exposure to the wild type virus.'

There are different assessment regarding the protective immunity threshold for mumps ranging from $9 \cdot-94 \%{ }^{17}$ and $\mathrm{v}_{0-17 \%}{ }^{1 \mathrm{~V}}$. The seropositivity in the present study for Mosul population ( $71 \%$ ) which is lower than the lower limit of the mumps protective immunity threshold range needed to prevent mumps epidemics.

Although ELISA is highly sensitive test, but recently it has been shown that ELISA had sensitivity around $1 . \%$ in comparison with the neutralization test. ${ }^{\prime \wedge}$ It might also be possible that the epitopes of mumps antigen employed by the ELISA kit do not entirely recognized antibodies induced by strain of virus isolated in Iraq. Whatever the reasons are, mumps

r.1. Mosul College of Pharmacy vaccination programme should be evaluated in Iraq.

\section{References}

1. Strauss EG, Strauss JH. Replication strategies of single stranded RNA viruses of eukaryotes. Cur. Top. Microbiol. Immunol 19人r;1.0: 0 0_or

r. Feldman HA. Mumps. In: Viral infections of human; Epidemiology and Control. Edited by Evans AS, New York, Platenum Medical 19Ar, $\mathrm{pp} \leqslant 19$.

r. Baum SG, Litman N. Mumps virus. In: Principle and Practice of Infectious Diseases. Edited by Mandell GL et al., $\varepsilon^{\text {th }}$ edit London Churchill Livingstone, $19190, \mathrm{pp} 1 \leq 9 .-10.1$.

£. Galazka AM, Robertson SE, Kraigler A. Mumps and mumps vaccine: a global review. Bull WHO 1999; $\left.\vee(1): r_{-}\right) \varepsilon$.

- Leinikki P. Mumps In: Principle and practice of clinical virology. Edited by Zuckerman AJ et al., New York; A Wiely Medical Publication, John Wiely and Son, 19Av, pp roo.

7. Gupta RK, Best J, MacMahon E. Mumps and the UK epidemic $r \ldots o$. Br Med J r...o; rr.:11rr-11ro.

$\checkmark$. Donaghy M, Cameron JC, Friederiches. Increasing incidence of mumps in Scotland: Options for reducing transmission. J Clin Virol, $r .$.$\urcorner ; ro: 1$ r $1 r 9$.

^. Osborn K, Weinberg J, Miller E. The European seroepidemiology network. Eurosurveillance $199 \mathrm{~V} ; \mathrm{r}: r q_{-} r$ l.

१. Papow-Kraupp T. Enzyme-linked immunosorbent assay (ELISA) for mumps virus antibodies. J Med Virol,

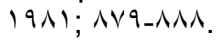

1. Andrews N, Pebody RG, Berbes G. Standardisating the enzyme immunoassay results for measles, mumps and rubella. Epidemiol infect, r...; r ro: 11 r-1ro.

1). Ukkonen P, Granstrm ML, Penttinen K. Mumps-specific immunoglobulin $M$ and $G$ antibodies in natural mumps infection as measured by enzyme-linked immunosorbent assay. J Med Virol

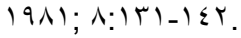

Ir. Nardone A, Pebody RG, VanDen Hof S, Levy-Bruhl D, et al. Seroepidemiology of mumps in western Europe. Epidemiol infect, $r \cdots r ; 1 r(1)$ : $r q 1-v \cdot 1$. 
Irq $\mathrm{J}$ Pharm Vol. ${ }^{9} \& 1 \cdot$, No. 1 ,

$r+1$.

1r. VanDen Hof S, Beaamont MTA, Berbes G. Antibodies against mumps in Netherland as assessed by indirect assay. Epidemiol infect, r..r; $1 r(1)$ : $V \cdot r-v \cdot q$.

I . Muhsen Kh, Aboudy Y, Mendelson E, Green MS. Prevalence of mumps antibodies in the Israeli population in relation to mumps vaccination policy and incidence of disease. Epidemiol infect $Y . . . v ; 1-$. .

10. Dayan GH, Quinlisk MP, Parker AA, et al. Recent resurgence of mumps in the

United States. N Engl J Med, Y..^; ro1:101.-1019.

17. Anderson RM, May RM. Immunisation and herd immunity. Lancet $199 \cdot ; r r 0$ : $7 \leqslant 1-7 \leqslant 0$.

IV. Fine PE. Community immunity. In: Plotkin SA, Orenstein WA, Eds, Vaccines, Philadelphia: Elsevier Inc., r... , pp. $1 \leqslant \leqslant r-1 \leqslant 7$.

1^. Backhouse JL, et al. Evaluation of two enzyme immunoassays for detection of immunoglobulin $\mathrm{G}$ antibodies to mumps virus. Clinical and Vaccine Immunology r... T IT: VTE-VTV.

$\underline{r \cdot 1 \cdot \text { Mosul College of Pharmacy }}$ 